\title{
THE STATE RESPONSIBILITY TO HEALTH FINANCING IN ENSURING UNIVERSAL COVERAGE FOR ALL INDONESIAN CITIZENS
}

\author{
Mainita \\ $\mathrm{PhD}$ in Law Program, Graduate School \\ University of Sumatera Utara \\ Medan, North Sumatra, Indonesia \\ mainitaita@yahoo.co.id
}

\author{
Ningrum Natasya Sirait \\ $\mathrm{PhD}$ in Law Program, Graduate School \\ University of Sumatera Utara \\ Medan, North Sumatra, Indonesia \\ ningrum.sirait@gmail.com
}

Abstract-WHO agreed with Universal Health Coverage (UHC) as a health system for every citizen in a state to have access for preventive, curative and qualified rehabilitative services based on the low cost. Currently, Indonesia is in the transition period to universal health service coverage. Law Number 40 of 2004 on National Social Security System is known as the answer of UHC. It requires everyone who is living in Indonesia to have access to comprehensive health services through a pre-paid system.

This study aimed to know the management and policy of Indonesia in health financing and the integrity of Local Health Insurance which provided by Local Government. This research is a mixed research of qualitative, quantitative, and normative law research. The data of this research were secondary data composed of (a) primary legal materials in the form of laws and regulation, and (b) secondary legal materials that include books and journals. The data were collected using literature reviews and document analysis. The data were analyzed using a conceptual approach and statue approach. The theory used in this research was the stakeholder theory of modern corporation.

In terms of management, at the end of 2011, Indonesia issued Law Number 24 of 2011 onSocial Security Board or well-known as BPJS (Badan Penyelenggara Jaminan Sosial) in order to implement the Law Number 40 on National Social Security System (SJSN). Furthermore, Article 1 Paragraph (1) of Law on BPJS states that BPJS is a legal entity established to organize social security programs.

Key Words: Universal Health Coverage; state responsibility; social security;

\section{INTRODUCTION}

Health is a human right that must be protected and given attention by the government because,in addition to economic and social indicators, health is also one of the indicators of public welfare. One of the government's efforts in improving public health is by buidling hospitals in each region.

In general, health serviceismentioned in two articles of the amendmentof the 1945Constitution of the Republic of Indonesia:(i) Article $28 \mathrm{H}$ Paragraph (1) which reads: "Each person has a right to live a peaceful life, to have a place to reside, to acquire a good and healthy living environment, and to obtainhealth service, and (ii)Article 34 Paragraph (3) which reads: "The state has the responsibility to provide proper medical and public service facilities".

In addition, health service is also mentioned in two articles of Law Number 36 of 2009 on Health: (i)Article 52 Paragraph (1) "health servicecomprises: a. personal health service, and b. public health service",paragraph (2) "health service as referred to in Paragraph (1) shall include activities with promotive, preventive, curative and rehabilitative approaches"; and (ii) Article 53 Paragraph (1) "personal health serviceis aimed at curing diseases and recovering the health of individuals and families", Paragraph (2): "public health service is aimed at maintaining and promoting health and preventing disease for a group and community".

The 1945 Constitution affirms "every citizen has the right to have access to health care and the state is responsible for providing health services to all its citizens". In Article 19 Paragraph (1) of Law Number 40 of 2004 on National Social Security System, it is mentioned that "health insurance is held nationally based on social insurance and equity principles". Through compulsory membership system in social health insurance, it can collect resources from the public as the capital forhealth financing, reducing the direct payment system (out of pocket) and improving pre paid system so that universal health coverage can be realized. 
Financing sources from the central government and local government (province and regency/city) come from taxes (general and sales), financial deficits (foreign loans) and social insurance. Meanwhile, private sector financing is sourced from companies, private health insurance, social donations and household expenditures.

In terms of its management system, at the end of 2011 Law Number 24 of 2011 on Social Security Board (BPJS) was issuedin order to implement the constitutional mandate of Law Number 40 of 2004 on National Social Security System (SJSN). The implementation of national health insurance is carried out by BPJS, as mandated by Article 1 Paragraph (1) of Law on BPJS stating that BPJS is a legal entity established to organize social security programs. According to Article 2 of Law on BPJS, BPJS has the duty to organize National Social Security System based on the principles of humanity, benefit, and social justice for all Indonesian people. In this case, it is clear that all forms of implementation of the National Social Security System are organized nationally by BPJS, including health insurance therein. This is reinforced by Article 6 of Law on BPJS stating that BPJS on Health organizes a health insurance program.

In some focus group discussions with stakeholders conducted by the Ministry of Health, various necessary substantive materials cannot be simply incorporated into the regulations but should integrate various health insurance schemes that have been implemented in the regions. The focus of the current SJSN preparation is addressed to the implementation of the Social Security Board (BPJS). BPJS will focus on health financing authorities as mandated by the Law. Therefore, to prevent overlapping authorities between the central government, localgovernment and BPJS, health insurance financing should be integrated earlier, as there will be no gap in the authority and responsibility of the government.

The dimension of policy appropriateness and the dimension of policy recommendation are used to assess the current alternatives of JAMKESDA's(Local Health Insurance)administration pattern particularly in terms of its administration management, benefits package and premium assistance along with theirproblems and challenges. In addition, such dimensions are also used to assess the alternatives of the best practices of JAMKESDA'sadministration pattern that has been runningin accordance with the pattern of strategic plan of JAMKESDA'sadministration based on the perspective of the local government (regency/city and province) and the central government.

According to Abidin (2004), several criteria commonly used to measure the accuracy of public policy formulation include political feasibility, economic feasibility, financial/cost feasibility, administrative feasibility, technological feasibility, socio-cultural feasibility and other feasibilitiescorresponding to the criteria that have specifically been formulated.
Health problems cannot be solved properly without adequate funding support. Health financing is the factor that affects the meaningful quality of a country. Indonesia is categorized as a country with low health financing with an average of $2.2 \%$ of Gross Domestic Product (GDP) and \$87 per capita, a value that is far from the WHO recommendation, at least $5 \%$ of GDP per year. Health financing is formulated in the health matters contained in the State Government Budget (APBN) or Local Government Budget (APBD). Health financing is allocated to health offices and as subsidized funds for each state-owned hospital. Hospital financing is composed of income and expenditure.

Evaluation on the policy should be focused more on its objective of serving people and the society. Surveys onservices provided by state-owned hospitals are also required by both the hospitals as service providers and other policymaking parties such as health office. Therefore, the problems can be used as an agenda for further policy determination to achieve the main purpose of improving health services to the people.

\section{FORMULATION OF THE PROBLEM}

Based on the background elaborated above, then the problem is formulated as follows:

1. How is the country responsibile for health financing towards Universal Coverage?

2. How is the Jamkesda'sintegrationinto JKN program towards Universal Coverage?

3. How does Jamkesda manage its administration, probability and quality in ensuring Universal Coverage?

\section{RESEARCH METHODOLOGY}

This research is a mixed research of qualitative, quantitative, and normativelaw research. The data of this research were secondary data composed of (a) primary legal materials in the form of laws and regulation, and (b) secondary legal materialsthat include books and journals. The data were collected using literature reviews and document analysis. The data were analyzed using a conceptual approach and statue approach.The theory used in this research was the stakeholder theory of modern corporation.

\section{FINDINGS AND DISCUSSION}

A. Analysis of administration management pattern, benefits package, and target of beneficiary of local health insurance fee

The results of the research conducted in 6 provinces, namely Aceh, West Sumatra, Gorontalo, DKI Jakarta, East Nusa Tenggara and Riau Islands show the model of financing with different effectiveness and success. This is in line with Murti (2010) arguing that the implementation of universal 
health service system varies across countries, depending on the extent of the government involvement in providing health services and health insurance. This is corresponding to the reality of Indonesia wheredecentralization effects are highly visible in health financing, as evidenced by the varied models of Jamkesda administration in Indonesia.

\section{$B$. Policy on health financing management pattern}

The policy is implemented by using a top-down approachbased on which the policy is formulatedby the central government, while the local governments are obliged to implement it. A policyis generally defined on a macro scale resulting in socioeconomic changes obviously realized in the presence of local government regulations which directly regulate its implementation in the regencies/cities (top-down approach) taking people without health insurance and poor people as its target. In addition to looking at the management pattern implemented in the local governments in Indonesia, it is also necessary to review the management pattern implemented by the United States government through Obama Care (the Affordable Act).

In the context of the administration management pattern of Obama Care financing, two points need to be recorded: 1) the transfer of authority of financing management to the central government is based on the interests of the local government, this is similar to the JKKK's effort to be integrated to JKN in Indonesia, and 2) the management refers to the stock exchange system insurance which is not managed directly by the central government; this is different from the central government in Indonesia that directly manages through the BPJS.

The policy of Obama Care is a centralized financing system, but it does not eliminate equality of opportunities, instead,it opens new preferences for the community. This principle should become one of the references for Indonesia, because the JAMKESDA integration process must keep running and centered but the central government should be able to provide options for the local government to adjust its regional conditions to the standard conditions expected by the central government.

Evaluation on the policy should be focused more on its objective of serving people and the society. Surveys on services provided by state-owned hospitals are also required by both the hospitals as service providers and other policymaking parties such as health offices. Therefore, the problems can be used as an agenda for further policy determination to achieve the main purpose of improving health services to the people.

\section{Comparison of Health Insurance Systemin Several Countries}

Universal Health Coverage(UHC) in Indonesia was actually done much earlier than in the United States through
Law on SJSN. However, the readiness of the United States in implementing Universal Health Coverage is due to its health system which is basically more prepared and more comprehensive. The readiness should not only be seen from health service facilitiesand financing system but it should also involves the readiness in providing a preventive promotive system that involves the participation of the community as a whole.

Obama Care is very concerned about the issue of health decentralization, and Indonesia is also facing the same experience in the context of Jamkesda which is currently running in various regions with their respective systems. In this case, the consideration of decentralization including the determination of organization pattern, benefits package and participant coverage should be implemented in the further application of universal health coverage in Indonesia so that the people will obtain maximum and sustainable benefits.

The comparison between the Philippinesand Indonesia's health insurance system is that the UHC formulation in the Philippines began in 1994, approximately ten years earlier than in Indonesia that initialized the reforms in 2005-2006 as the preparation for the reforms in 2014. Earlier implementation of UHC makes the Philippinesmore advanced than Indonesia in its health system whose health insurance budget reaches 9 billion pesos or equivalent to 2.4 trillion rupiah.From the financial aspect, the Philippines budgeted the health insurance. The existence of decentralization of health systems in the Philippines is quite similar to the Jamkesda system in Indonesia, although it is basically more integrated and formulated.

\section{CONCLUSIONS}

The policy is implemented by using a top-down approach based on which the policy is formulated by the central government, while the local governments are obliged to implement it. A policy is generally defined on a macro scale resulting in socioeconomic changes. The policy evaluation conducted by the policy makers reports that the evaluationhas been well-conducted on a regular basis. Nevertheless, the results of the evaluation by the patients show that there are still many weaknesses that should be improved such as the doctor's lack of clarification, delayed drug administration, sanitation, and doctor's different way of communication with patients from different ward level.

To make the integration of Jamkesda to the National Health Insurance comprehensivelycentralized but keep providing space for the local government, the results of this research formulatean integrated policy formulation called Dynamic Centralization Policy Formulation. It adopts centralization policy because it is formulated as the Centralized National Health Security System, but it is dynamic because it keeps opportunities to the local governments through its decentralizationframework. 
In the context of administration management pattern in the United States,it transferred the authority of financing management to the central government based on the interests of the local government. This is similar to the Jamkesda's effort to be integrated to JKN in Indonesia whose management refers to the stock exchange system insurance which is not managed directly by the central government; this is different from the central government in Indonesia that directly manages through BPJS.

Portability factors often serve as an obstacle in the Jamkesda. This tends to lead to data overlapping if the government is not able to well integrate inter-regional data, the role of the central government to collect the data in one institutional is required, so that the principle of portability in JKN can run optimally.

\section{ACKNOWLEDGEMENTS}

The authors would like to thank the provider of Indonesian Lecturer's Domestic Scholarship (BUDI-DN) that makes it possible for the writer to complete this research and publish it in an international journal.

\section{REFERENCES}

[1] Abidin, said zainal, Kebijakan Publik, Yayasan Pancur siwah: Jakarta

[2] Bappenas, Desain Sistem Perlindungan Sosial Terpadu, Direktorat Kependudukan, Kesejahteraan Sosial, dan Pemberdayaan Perempuan, 2003.

[3] BPS, Sensus Penduduk 2010, 2011.

[4] Dunn, WN, Pengantar Analisis Kebijakan Publik, Edisi Kedua, Gadjah Mada University Press: Yogyakarta, 2003

[5] Gani, A. Dkk, Laporan Kajian Sistem Pembiayaan Kesehatan di Beberapa Kabupaten dan Kota, Pusat Kajian Ekonomi Kesehatan dan Analisis Kebijakan, Fakultas Kesehatan Masyarakat Universitas Indonesia, Depok , 2008.

[6] Mukti, Ali Gufron, Reformasi Sistem Pembiayaan Kesehatan di Indonesia dan Prospek ke Depan, PT. Karya Husada Mukti: Yogyakarta, 2007

[7] Murti, Bisma, Strategi untuk Mencapai Cakupan Universal Pelayanan Kesehatan di Indonesia, disampaikan pada Temu Ilmiah Reuni Akbar FKUNS, di Surakarta, 2010.

[8] Pokharel, B, Decentralization of Health Services, ICP OSD 1, WHO Project, 2000.

[9]

Act The Affordable Care, diunduh dari www.healthcare.gov/law/full/
$[10]$

WHO, Achieving Universal Health Coverage: Developing the Health Financing System. Technical Brief for Policy-makers. Number 1, 2005. World Health Organization, Department of Health Systems Financing, Health Financing Policy, 2005.

[11] Undang-Undang Dasar 1945

[12] Undang-undang Nomor 32 tahun 2004 tentang Pemerintahan Daerah

[13] Undang-undang Nomor 40 Tahun 2004 tentang Sistem Jaminan Sosial Nasional

[14] Undang-undang No. 25 Tahun 2009, tentang Pelayanan Publik

[15] Undang-Undang Nomor 36 Tahun 2009 tentang Kesehatan (Lembaran Negara Republik Indonesia Tahun 2009 Nomor 144, Tambahan Lembaran Negara Republik Indonesia Nomor 5063)

[16] Undang-Undang Nomor 44 Tahun 2009 tentang Rumah Sakit (Lembaran Negara Republik Indonesia Tahun 2009 Nomor 153, Tambahan Lembaran Negara Republik Indonesia Nomor 5072)

[17] Undang-undang Nomor 24 Tahun 2011, tentang BPJS

[18] Peraturan Pemerintah Nomor 32 Tahun 1996 tentang Tenaga Kesehatan (Lembaran Negara Republik Indonesia Tahun 1996 Nomor 49, Tambahan Lembaran Negara Republik Indonesia Nomor 3637) Peraturan Pemerintah Nomor 38 Tahun 2007 tentang Pembagian KEP-117/M-MBU/2002 